This PDF is a selection from a published volume from the National Bureau of Economic Research

Volume Title: Health and Labor Force Participation over the Life Cycle: Evidence from the Past

Volume Author/Editor: Dora L. Costa, editor

Volume Publisher: University of Chicago Press

Volume ISBN: 0-226-11618-2

Volume URL: http://www.nber.org/books/cost03-1

Conference Date: February 2-3, 2001

Publication Date: January 2003

Title: The Significance of Lead Water Mains in American

Cities. Some Historical Evidence

Author: Werner Troesken, Patricia E.. Beeson

URL: http://www.nber.org/chapters/c9632 


\title{
The Significance of Lead Water Mains in American Cities Some Historical Evidence
}

\author{
Werner Troesken and Patricia E. Beeson
}

\subsection{Introduction}

By the turn of the twentieth century, cities throughout the United States were using lead service mains to distribute water. For example, in 1900 the nation's five largest cities_-New York, Chicago, Philadelphia, Saint Louis, and Boston - all used lead services to varying degrees (Baker 1897, 42, 89, 170, 373, 501). Despite the fact that many of these mains are still in use and that up to 20 percent of all lead exposure in young children comes from drinking water, the significance of lead service mains is poorly understood and there exists little scientific evidence that would allow us to precisely measure their effects on human health (U.S. Environmental Protection Agency 2000).

The dearth of information and scientific study on lead services is unfortunate. It is well known that ingesting even small amounts of lead can adversely affect health and mental development, particularly among children (Needleman and Belinger 1991). Moreover, the Centers for Disease Control (1997) estimate that as many as 5 percent of all American children suffer from subclinical lead poisoning. There are, as a result, numerous studies exploring the health effects of exposure to lead through soil (Xintaras 1992), paint and house dust (Lanphear and Rogham 1997), industrial pollution (Trepka et al. 1997), leaded gasoline (Charney, Sayre, and Coulter 1980), and work environments (Sata et al. 1998). The importance of lead dissolved

Werner Troesken is associate professor of history and economics at the University of Pittsburgh. Patricia E. Beeson is professor of economics at the University of Pittsburgh.

We gratefully acknowledge helpful comments and advice from Dora Costa, Robert Fogel, Joel Tarr, Peter Viechnicki, and conference participants, and especially Rebecca Menes. The usual disclaimer applies. 
from lead service mains has received much less attention, in part because over time oxidation has created a protective coating over the interior walls of lead pipes and limited the levels of lead ingested through drinking water (Wisconsin Department of Natural Resources 1993). Nonetheless, it would be useful to know just how widespread lead water mains are, and how they have affected human health both today and in the past.

Accordingly, our goals in this paper are twofold. First, we explore how many cities in the United States used lead services during the late nineteenth and early twentieth century and we examine what factors influenced the choice to use lead mains. The results indicate lead service mains were pervasive: 70 percent of all cities with populations greater than 30,000 in 1900 used lead service mains exclusively or in combination with some other type of main. As for the correlates of lead usage, the probability of using lead water mains was positively correlated with city size, a Midwestern location, and public ownership (publicly owned water companies used lead more often than did private water companies). Second, we explore how the use of lead service mains affected morbidity around the turn of the twentieth century. The evidence on morbidity is derived from a large sample of Union Army veterans whose health was assessed when they applied for pensions. Overall, our results suggest that the use of lead water mains probably did have some adverse effect on human health, but for the general population, these effects do not appear to have been very serious. For example, Union Army recruits living in cities that used lead service mains appear to have experienced more ailments associated with low levels of lead exposure, such as dizziness and hearing problems, but they did not suffer from more serious ailments associated with high levels of lead exposure, such as kidney problems.

Whatever implications these results might have for current policy, they should also interest historians and historical demographers. Some historians attribute the decline of Rome to the use of lead-lined water mains and lead-based vessels to distill alcohol and store water (Waldron and Stöfen 1974, 4-6). More recent studies have explored the possibility that prominent historical figures such as U.S. president Andrew Jackson (Deppisch et al. 1999) and the painter Francisco de Goya died of lead poisoning (Ravin and Ravin 1999). On a broader scale, several recent studies document tremendous improvements in human health and life expectancy over the past century and a half (e.g., Costa 2000; Fogel 1986; Fogel and Costa 1997). While the factors that contributed to this improvement are generally well known and include improved nutrition, investments in public water and sewer systems, the development of vaccines and antibiotics, etc., the relative and absolute importance of these various factors is much less clear. This paper helps to clarify the importance of one of these factors: the reduced risk of unhealthy levels of lead exposure. 


\subsection{The Use of Lead in Plumbing and Water Distribution Systems}

In the late nineteenth- and early twentieth-century United States, lead was often used in the construction of water service mains. This section explains what service mains were, and some of the engineering concerns that prompted many cities to use lead services. Service mains were the pipes that connected individual homes and apartment buildings to street mains. The decision to install a service main was three dimensional, involving a choice about material, a choice about internal lining, and a choice about size. Services were made of iron, steel, or lead; if iron or steel, they were sometimes lined with lead or cement; and they typically ranged in size from threequarters of an inch to one and one-quarter inches in diameter (Baker 1897).

The choices about material, lining, and size were influenced by the following five variables: cost of pipe; malleability; propensity for external corrosion; propensity for internal corrosion; and toxicity. Table 7.1 ranks the most common pipe types in terms of these variables. As for the first variable, the cost of materials, a small (three-quarter-inch) iron or steel pipe that was neither galvanized nor lined was the best choice. The primary drawback of this choice, however, was that small untreated iron pipes were subject to corrode sooner than other alternatives. Because replacing broken service mains often required digging up paved streets and working around other infrastructure such as gas and sewer mains, the costs of reduced main life often overwhelmed whatever savings were generated from reduced materials costs. As for the second variable, malleability, lead was a relatively soft and pliable metal and was the best choice. Malleability reduced labor costs by

Table 7.1

The Costs and Benefits of Some Common Types of Service Main

\begin{tabular}{lccccc}
\hline Main Characteristics & $\begin{array}{c}\text { Cost of } \\
\text { Material }\end{array}$ & Malleability & $\begin{array}{c}\text { External } \\
\text { Corrosion }\end{array}$ & $\begin{array}{c}\text { Internal } \\
\text { Corrosion }\end{array}$ & Toxicity \\
\hline $\begin{array}{l}\text { Material and lining } \\
\text { Plain iron or steel }^{\mathrm{a}}\end{array}$ & 1 & 3 & 3 & 5 & 2 \\
Galvanized iron or steel $^{\mathrm{a}}$ & 2 & 4 & 2 & 4 & 1 \\
Lead $^{\text {Iron: cement-lined }}$ & 4 & 1 & 1 & 2 & 3 \\
Iron: lead-lined & 3 & 3 & 2 & 1 & 2 \\
Size of pipe & 3 & 2 & 2 & 3 & 3 \\
Small (3/4" diameter) & 1 & & & 3 & \\
Medium (1" diameter) & 2 & & & 1 & \\
Large (1 1/4" diameter) & 3 & & & & \\
\hline
\end{tabular}

Source: Engineering News, 28 September 1916, pp. 594-97.

anlined.

${ }^{b}$ Exterior of pipe, galvanized iron; interior of pipe, cement.

${ }^{c}$ Exterior of pipe, galvanized iron; interior of pipe, lead. 
making it easier to bend the service main around existing infrastructure and obstructions (Engineering News, 28 September 1916, pp. 594-96).

As for the third variable, external corrosion, service mains were subject to corrosion from the outside, and mains laid in salt marsh, cinder fill, or clay experienced faster degradation than those laid in sand or gravel. Holding soil type constant, steel and iron services, whether plain or galvanized, experienced faster corrosion than lead services. If local authorities wanted to minimize the number of times services burst from external corrosion and required replacement, lead was the best choice (Engineering News, 28 September 1916, pp. 594-96).

As for the fourth variable, internal corrosion, service mains were subject to corrode from the inside as a result of contact with stagnant water. Interior corrosion was a concern because it weakened the pipe and increased the risk of a rupture, and because rust deposits built up and clogged the main. Before 1910, there was no effective technique for cleaning out rustfilled mains other than by digging them up and cleaning them out directly or by replacing the mains. Cement-lined service mains exhibited the least internal corrosion. Although not as resistant to internal corrosion as cement-lined pipes, lead services were subject to less corrosion than galvanized iron and steel. Another strategy for minimizing the problem of internal corrosion was to expand the size of the main, for the simple reason that the larger the diameter of the main the more rusted material necessary to clog the main.

It is important to note that the amount of internal corrosion depended not only on the type material used to construct the service pipe; it also depended on the corrosiveness of the water being distributed. As a general rule, water from underground wells and water that had been filtered was more corrosive than unfiltered water from above-ground sources. The corrosiveness of water also varied across regions: New England had particularly corrosive water (Engineering News, 28 September 1916, pp. 594-96).

As late as 1916, most engineers believed the benefits of using lead mains outweighed the potential costs. The Engineering News, a prominent trade journal, explained: ${ }^{1}$

Lead is in many respects the most satisfactory material to use for service pipes. Its pliability and its comparative freedom from corrosive action make it almost ideal from a mechanical standpoint. The cost of lead pipe of sufficient thickness to safely withstand the pressure is more than the cost of many other materials used for services, but in a paved street the greater duration of life probably more than compensates for the extra cost, and in places where the streets are occupied by other pipes and con-

1. Beyond lead service mains, lead pipes were also used widely in household plumbing and in the solder used to connect iron pipes. The same features that made lead attractive for services also made it attractive for plumbing; lead was malleable and allowed plumbers to fit pipes around existing fixtures, and it did not corrode like iron. 
duits the ease of getting over and under these obstructions with a flexible pipe is a great advantage. (16 September 1916, p. 595)

The same journal went on to confront, but then minimize, concerns about lead poisoning:

The most serious objection to the use of lead pipe for services is the possibility that the water may dissolve enough lead from the pipe to cause lead poisoning. It is certain that many cases of lead poisoning have been caused by the use of lead services. On the other hand, lead has always been used for services in most of the large places without any unfavorable effects. (28 September 1916, p. 595)

While it is true that most large cities did not incur substantial ill effects from the use of lead services, there were a handful of cases where the installation of lead service mains did have serious consequences. For example, after lead service mains were installed in Lowell and Milton, Massachusetts, around the turn of the twentieth century, several people died, and others suffered dementia and permanent nerve damage, because of lead ingested through drinking water. Following the poisonings in Lowell and Milton, the State Board of Health in Massachusetts began urging cities and towns in the state to avoid installing lead service mains. In addition, families of those injured by lead sued, and won, judgments against the cities and water companies that installed the lead services. Officials at the water companies in question later suggested that the use of lead services would not have had such deleterious effects had local water supplies not contained unusually large amounts of carbonic acid. Carbonic acid dissolved lead from the interior of service pipes and was introduced into the water partly by nature and partly through filtration and chlorination. ${ }^{2}$

\subsection{Limiting Exposure to Lead through Lead Service Mains and Lead Plumbing}

Today, the Environmental Protection Agency (EPA; 2000) recommends three steps to minimize the amount of lead in drinking water. First, households should flush their pipes before drinking the water. Because the amount of lead that dissolves into water is positively related to the time it sits in the pipes, running faucets for two minutes clears most leadcontaminated water. Second, households should use only cold water for drinking and cooking because hot tap water contains higher lead levels. Third, households should have their water tested to accurately measure its

2. See "Report of the Committee on Service Pipes" (1917, especially 354-59); and Welsh v. Milton Water Company, 200 Mass. 409 (1909). Also, at this point in our analysis, it is not clear to us which segments of society were most harmed by the installation of lead mains in these cities. In future work, we hope to identify the effects on different social groups such as children and the poor. 
lead levels. According to the EPA, testing is especially important for individuals and families living in large apartment complexes, because flushing may not be effective in high-rise buildings with lead-soldered plumbing. It is not clear how many families at the turn of the century were aware of these simple preventive measures. Prominent engineering journals such as the Engineering News (28 September 1916, p. 595) argued that it was difficult to predict how much lead dissolved into water from water mains and recommended testing drinking water for lead content as the only safe guide to assessing levels of exposure:

It seems practically impossible to determine definitely in advance what the effect of any water on lead pipe will be, as the laboratory results fail in many cases to show the action which will occur in actual practice. Tests of service pipes in use for a considerable period are the only safe guides.

Such lukewarm recommendations notwithstanding, it seems unlikely that most families would have been sufficiently concerned about lead in drinking water to motivate them to have had their water tested, or even to have flushed their pipes regularly. Recent studies suggest people were much more concerned about bacteriological pollution (e.g., typhoid) than they were about industrial and chemical pollution of water. Some experts even believed that a minimal level of industrial contaminants in water could be beneficial because it killed off otherwise harmful bacteria (Melosi 2000, 241-46). Moreover, it was not until the 1930s that states began passing laws regulating the amount of lead present in plumbing and water distribution systems, and it was not until 1986 that Congress banned the use of leadbased solder in plumbing (EPA 2000; Wisconsin Department of Natural Resources 1993). Finally, lead-based interior paints were marketed well into the mid-twentieth century (Markowitz and Rosner 2000).

\subsection{The Frequency and Correlates of Lead Usage}

At the turn of the twentieth century, the use of lead service mains was widespread, particularly in large cities. This can be seen in two independent samples of cities. In 1916, the New England Water-Works Association surveyed 304 cities and towns, largely in the New England area, and found that 95 (31 percent) of these cities used lead or lead-lined services exclusively (Engineering News, 28 September 1916, p. 594). Another sample, predicated on the sample of Union Army recruits described below (see also Fogel 2000), is more geographically diverse and includes 797 cities and towns observed in 1900 from all over the United States. Of these cities, 209 (26 percent) used lead or lead-lined services exclusively; 137 (17 percent) used lead or lead-lined services in conjunction with some other material type, such as galvanized iron or cement-lined iron; and 451 (57 percent) used no lead. Table 7.2, which breaks down the usage of lead service mains by city size, 


\begin{tabular}{lcrrr}
\hline & \multicolumn{3}{c}{ Number of Cities, by Service Main Type } \\
\cline { 3 - 5 } City Size & $\begin{array}{c}\text { Total Number } \\
\text { of Cities }\end{array}$ & $\begin{array}{c}\text { Only } \\
\text { Lead }\end{array}$ & $\begin{array}{c}\text { Lead and } \\
\text { Other }\end{array}$ & $\begin{array}{c}\text { No } \\
\text { Lead }^{\mathrm{b}}\end{array}$ \\
\hline Population $>300,000$ & 16 & $8(50 \%)$ & $7(44 \%)$ & $1(6 \%)$ \\
$30,000<$ population $<300,000$ & 107 & $55(51 \%)$ & $22(21 \%)$ & $30(28 \%)$ \\
$8,000<$ population $<30,000$ & 156 & $46(29 \%)$ & $36(23 \%)$ & $74(47 \%)$ \\
Population $<8,000$ & 518 & $100(19 \%)$ & $72(14 \%)$ & $346(67 \%)$ \\
All towns and cities & 797 & $209(26 \%)$ & $137(17 \%)$ & $451(57 \%)$ \\
\hline
\end{tabular}

Sources: Data on services are from Baker (1897). The sample is restricted, however, to only cities and towns represented in the Union Army data. See Fogel (2000).

${ }^{a}$ Cities using lead or lead-lined service mains exclusively.

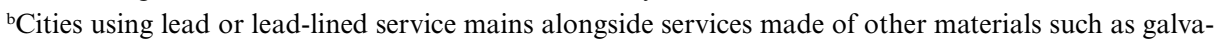
nized iron or cement-lined.

${ }^{\mathrm{c}}$ Cities using nonlead service mains exclusively.

suggests a strong positive correlation between lead usage and city size. For the largest cities, those with populations greater than 300,000, only 1 of 16 used no lead in its system of service mains. In contrast, for cities with populations less than 8,000, the majority (67 percent) used no lead whatsoever.

To more fully identify the correlates of using lead service mains, we estimate variants on the following ordered-probit model:

$$
L_{i}=\delta_{0}+X_{i} \boldsymbol{\delta}_{1}+\varepsilon_{i},
$$

where $L_{i}$ is an indicator variable that equals 2 if city $i$ used lead service mains exclusively as of 1900, 1 if city $i$ used lead services in conjunction with some other material, and 0 if it used no lead services; $\boldsymbol{X}_{\boldsymbol{i}}$ is a vector of city characteristics that might have been correlated with main type, including city size, age of water system, region dummies, ownership of local water company (i.e., whether public or private), and measures of the development of other public infrastructure; and $\varepsilon_{i}$ is a random error term. Equation (1) is estimated using data for all cities with populations greater than 30,000 as of 1902, and for which the relevant data are available. Data on service mains and ownership of local water systems are from Baker (1897); other data are from the U.S. census of 1900 and the Statistics of Cities (U.S. Department of Commerce and Labor, Bureau of Labor, 1902). We restrict the sample to cities with populations greater than 30,000 because data for these large cities are more easily acquired.

Table 7.3 presents descriptive statistics, predicted signs, and regression results. There are few notable descriptive statistics. Most cities (70 percent) with populations greater than 30,000 used lead exclusively (53 percent) or in combination with some other type of service main (17 percent); 74 percent of all large cities had public water companies; the typical large city con- 


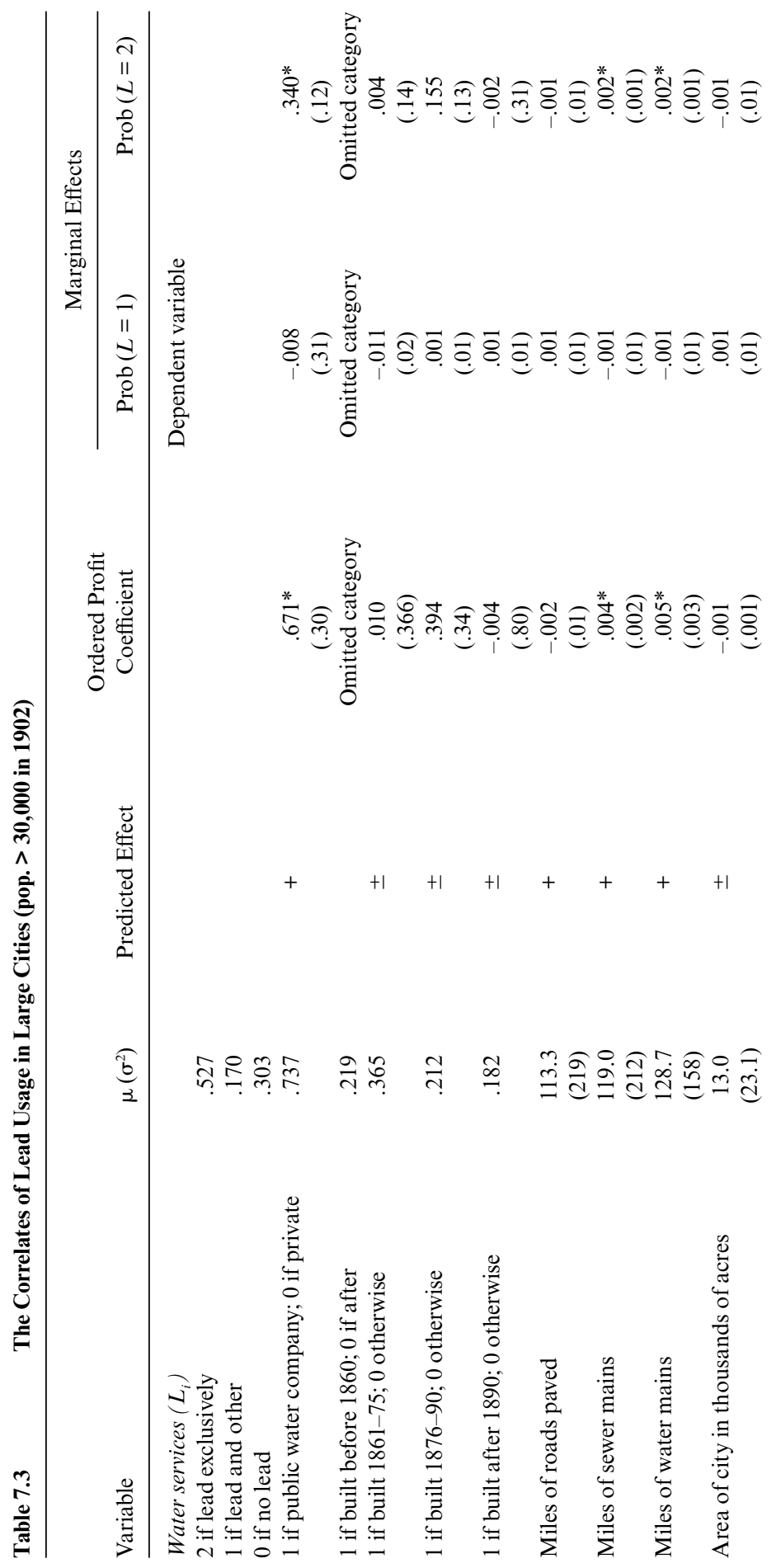




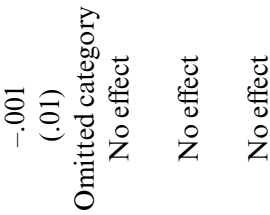

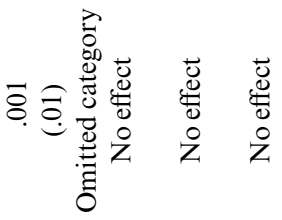

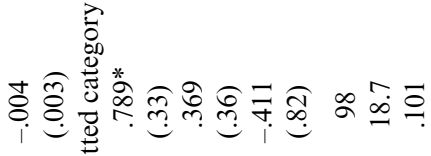

$$
\begin{aligned}
& +1+1+1+1
\end{aligned}
$$

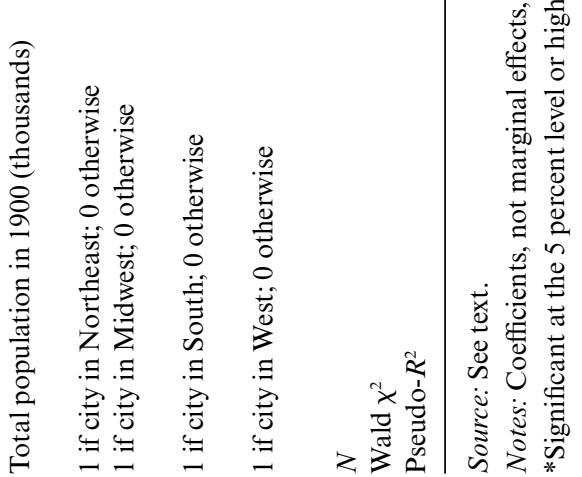


structed its waterworks before 1875; and half of all large cities (51 percent) were located in the Northeast.

Predicted signs are as follows. The effect of public ownership should be positive. Because private water companies were often vulnerable to political expropriation, they would have been more reluctant than public companies to invest in lead service mains, which were more expensive and more durable than iron mains (Troesken 1997). We expect the coefficients on the "decade-of-construction" dummies to grow smaller over time. During the late eighteenth and early nineteenth centuries, doctors used lead acetate to treat bleeding and diarrhea; whiskey distilleries used lead tubing to distill alcohol; and households frequently used vessels with a high lead content to cook and store drinking water. By 1900, such dubious practices had grown much less common, although as noted in the previous section, they certainly had not disappeared (Aufderheide et al. 1981; Deppisch et al. 1999). Along the same lines, as people learned from events like those that occurred in Milton and Lowell, Massachusetts, the use of lead water mains would have grown less common over time.

After controlling for city size in terms of population and acreage, miles of paved roads, sewer mains, and water mains should be positively correlated with the use of lead because well-developed infrastructure makes malleability and durability more attractive - recall that on both of these characteristics lead (as opposed to iron or cement-lined) service mains ranked high (see table 7.1). For example, in a city where most roads were paved, it was costly to have a service pipe burst because replacing the service also would have required digging up the pavement. A city with few paved roads would not have confronted such costs. Finally, the attractiveness of lead would have varied depending on the city's climate, soil quality, and corrosiveness of water. These factors are captured by the regional dummies.

The coefficients on ordered-probit models are not easily interpreted. Accordingly, in addition to reporting the estimated coefficients in table 7.3, we also report the estimated marginal effects for two outcomes: some lead (1); and all lead (2). The estimates indicate the model does a poor job predicting the first outcome (i.e., when a city would have used lead in combination with some other type of main). The model does a better job predicting the use of lead exclusively. Consistent with predictions, cities with public water companies and cities with well-developed infrastructure in terms of miles of water and sewer mains installed were more likely than other cities to have used lead service mains exclusively. Aside from the large number of insignificant explanatory variables, there is one result that is particularly surprising: The estimated effect of population is small. The descriptive statistics in table 7.2 would have suggested otherwise: The table suggests a strong, positive correlation between city size and the use of lead mains.

There are two possible reasons we might find little correlation between city size and the use of lead in formal regression analysis. First, if city size 
were correlated with other variables, such as the development of urban infrastructure, controlling for those other variables would reduce the correlation between city size and lead usage. However, dropping the other explanatory variables from the regression model still does not strengthen the observed correlation in these data. A second explanation is that once a city's population reached 30,000 , variation in population had little influence on its decision to use lead. (The sample used here is restricted to such cities.) This hypothesis is borne out by table 7.2, which shows that the use of lead drops off sharply only after population falls below 30,000 .

\subsection{The Health Effects of Lead}

Lead affects multiple systems in the human body, including the central and peripheral nervous system, the gastrointestinal tract, the kidneys, and the hematological (blood) system. Although further study is required, recent studies suggest lead might also adversely affect the human immune system (e.g., Cohen et al. 1989; Fischbein et al. 1993; Sata et al. 1998). Which of these systems is affected and to what degree depends on how much lead is ingested and the overall size and health of the person exposed. Table 7.4 sum-

Table 7.4

How Lead Affects Children and Adults

\begin{tabular}{|c|c|c|}
\hline \multirow[b]{2}{*}{ Lead Level in Blood } & \multicolumn{2}{|c|}{ Effects } \\
\hline & Children & Adults \\
\hline $0-9 \mu \mathrm{g} \mathrm{Pb} / \mathrm{dl}$ & Uncertain & Uncertain \\
\hline $10-19 \mu \mathrm{g} \mathrm{Pb} / \mathrm{dl}$ & $\begin{array}{l}\text { Decreased IQ, hearing, and growth; } \\
\text { decreased vitamin D metabolism; EP }\end{array}$ & Hypertension; EP ${ }^{\mathrm{a}}$ (women) \\
\hline $20-29 \mu \mathrm{g} \mathrm{Pb} / \mathrm{dl}$ & Decreased nerve conduction velocity & $\mathrm{EP}^{\mathrm{a}}(\mathrm{men})$ \\
\hline $30-39 \mu \mathrm{g} \mathrm{Pb} / \mathrm{dl}$ & & $\begin{array}{l}\text { Increased systolic blood pressure } \\
\text { (men); decreased hearing acuity }\end{array}$ \\
\hline $40-49 \mu \mathrm{g} \mathrm{Pb} / \mathrm{dl}$ & Decreased hemoglobin synthesis & $\begin{array}{l}\text { Peripheral neuropathies; }{ }^{\mathrm{b}} \text { infertility } \\
\text { (men); nephropathy }{ }^{\mathrm{c}}\end{array}$ \\
\hline $50-100 \mu \mathrm{g} \mathrm{Pb} / \mathrm{dl}$ & $\begin{array}{l}\text { Colic; frank anemia; nephropathy; } \\
\text { encyphalopathy }{ }^{\mathrm{d}}\end{array}$ & $\begin{array}{l}\text { Decreased hemoglobin synthesis; } \\
\text { decreased longevity; frank anemia; } \\
\text { encephalopathy }{ }^{\mathrm{d}}\end{array}$ \\
\hline$>100 \mu \mathrm{g} \mathrm{Pb} / \mathrm{dl}$ & Death & Death \\
\hline
\end{tabular}

Sources: Perazella (1996); Ravin and Ravin (1999); Xintaras (1992).

${ }^{a}$ Erythocyte protoporphyrin (changes in the shape and size of red blood cells).

${ }^{b}$ Nerve disorders in the extremities. Historically, such disorders might have manifested themselves as complaints about "rheumatism" in the hands and feet; gout; and wrist and foot drop.

${ }^{\mathrm{c}}$ Chronic or acute kidney failure.

${ }^{\mathrm{d}}$ Any brain-related disorder. Historically, such disorders might have manifested themselves in violent mood swings, memory loss, and dementia. 
marizes the effects of lead. At low levels of exposure (blood levels less than $20 \mu \mathrm{g} \mathrm{Pb} / \mathrm{dl}$ ), lead causes subtle changes in body chemistry and manifests itself in comparatively mild symptoms such as dizziness and hypertension in adults and developmental delays in children. At intermediate levels of exposure (blood levels between 20 and $40 \mu \mathrm{g} \mathrm{Pb} / \mathrm{dl}$ ), lead has more serious effects, including peripheral neuropathies, infertility in men, increased systolic blood pressure in adults, and reduced hemoglobin synthesis and vitamin D metabolism in children. At high levels of exposure (blood levels between 40 and $100 \mu \mathrm{g} \mathrm{Pb} / \mathrm{dl}$ ), lead causes nephropathy (chronic or acute kidney failure), frank anemia, and reduced hemoglobin synthesis in adults; and colic, nephropathy, and encephalopathy in children. At extremely high levels (blood levels exceeding $100 \mu \mathrm{g} \mathrm{Pb} / \mathrm{dl}$ ), lead will cause death.

Historically, it might have been difficult for doctors to accurately diagnose mild to moderate cases of lead poisoning. Deppisch et al. (1999) suggest that President Andrew Jackson's complaints of a severe and debilitating "rheumatism" in his right hand were consistent with peripheral neuropathy caused by lead poisoning. Because lead affects the gastrointestinal tract and can cause abdominal pain, anorexia, cramps, nausea, vomiting, and constipation, Jackson's many laments in this area also could have been related to exposure to toxic metals such as mercury or lead. Finally, it is possible that complaints about gout were related to plumbism (Ravin and Ravin 1999; Perazella 1996; Soliway et al. 1994).

\subsection{How the Use of Lead Water Mains Affected the Health of Union Army Veterans}

To assess the impact of lead service mains on human health we employ data from a large sample of Union Army recruits compiled by researchers affiliated with the University of Chicago (Fogel 2000). These data have been used in numerous published studies and readers unfamiliar with the data are directed to Fogel for a thorough description of the sample. There are only two significant differences between our study and previous work. First, it is necessary for us to supplement the Union Army data with information about the type of water mains used in the various towns where Union Army veterans resided. Data on the types of mains used (e.g., lead or galvanized iron) are from Baker (1897). Second, given the nature of the problem, we restrict the sample to Union Army recruits living in cities or towns with reliable information about their public water systems, and in particular, about the types of service mains used to distribute water. We use each recruit's address as of 1900 as his city of residence. ${ }^{3}$

3. This ignores the fact that many recruits moved. In future work, we will better control for this by including variables on years of exposure to lead. 
After restricting the data this way, we are left with a sample of 2,215 recruits. The sample is geographically diverse, with recruits living in forty different states as of 1900, although the Midwest and the Northeast are overrepresented. Thirty-seven percent of the recruits lived in cities or towns using no lead water mains whatsoever; 27 percent lived in cities or towns using both lead and iron mains; and 36 percent lived in cities or towns using lead mains exclusively.

Given the discussion in section 7.4, one might expect Union Army recruits living in cities with lead water mains, compared to recruits in cities with iron mains, to exhibit more of the following symptoms: dizziness, ear problems; deafness; memory loss; kidney tenderness and pain; and kidney disease ${ }^{4}$ Accordingly, we estimate variants on the following logit model:

$$
X_{i}=\beta_{0}+\beta_{1} L 1_{i}+\beta_{2} L 2_{i}+Z_{i} \beta_{3}+\varepsilon_{i}
$$

where $X_{i}$ is an indicator variable equal to 1 if by 1910 the recruit reported a specific ailment related to lead poisoning (e.g., hearing or kidney problems), and zero otherwise; $L 1_{i}$ is an indicator variable equal to 1 if the recruit resided in a city that used lead water mains in conjunction with other types of mains (e.g., iron) as of 1900, and zero otherwise (henceforth, we refer to this variable as the some-lead dummy); $L 2_{i}$ is an indicator variable equal to 1 if the recruit resided in a city that used lead water mains exclusively as of 1900 , and zero otherwise (henceforth, we refer to this variable as the all-lead dummy); $\boldsymbol{Z}_{i}$ is a vector of other related control variables, such as the recruit's occupation and health in 1900 , his wartime regiment, the size of the city where the recruit resided in 1900, and the size of the city where the recruit had enlisted; and $\varepsilon_{i}$ is an error term. The control variables included in $\boldsymbol{Z}_{i}$ are summarized in table 7.5, and for the most part, are identical to those employed in Costa (2000).

Table 7.6 reports the predicted effects of lead service mains under three conceivable hypotheses. The first hypothesis is that lead service mains had, at most, subclinical effects that did not manifest themselves in any ailments related to lead exposure and resulted in blood concentration levels less than $10 \mu \mathrm{g} \mathrm{Pb} / \mathrm{dl}$. Under this hypothesis, recruits living in cities with lead pipes as of 1900 would have experienced no more lead-related ailments than recruits living in cities without lead pipes, and the coefficients on lead water mains would be close to zero and statistically insignificant. One might expect results consistent with this hypothesis if people routinely flushed their pipes, used only cold tap water for cooking and drinking, and had their water tested. Results consistent with hypothesis 1 might also be obtained if the effects of lead service mains were overwhelmed by other sources of lead exposure we have not been able to fully control for, such as work-related ex-

4. It bears repeating that we are examining recruits that survived long enough to have been observed in 1910, and as a result, there is a concern about selection bias. 
Table 7.5

List of Control Variables

\begin{tabular}{|c|c|c|}
\hline & Individual Characteristics & City-Level Characteristics \\
\hline At time of enlistment & $\begin{array}{l}\text { Occupation } \\
=1 \text { if farmer } \\
=1 \text { if professional } \\
=1 \text { if artisan } \\
=1 \text { if laborer } \\
=1 \text { if skilled laborer } \\
=1 \text { if occupation unknown } \\
\text { Physical condition } \\
\text { Height } \\
\text { Weight }\end{array}$ & $\begin{array}{l}\text { City size } \\
\quad=1 \text { if }<4,000 \\
=1 \text { if }>4,000 \text { and }<30,000 \\
=1 \text { if }>30,000\end{array}$ \\
\hline During wartime & $\begin{array}{l}\text { Wounds, rank, etc. } \\
\begin{array}{l}=1 \text { if gunshot wound } \\
=1 \text { if prisoner of war } \\
=1 \text { if dishonorable discharge } \\
=1 \text { if private } \\
=1 \text { if injured } \\
\text { Illnesses } \\
=1 \text { if measles } \\
=1 \text { if diarrhea } \\
=1 \text { if respiratory } \\
=1 \text { if tuberculosis } \\
=1 \text { if typhoid } \\
=1 \text { if malaria } \\
=1 \text { if syphilis } \\
=1 \text { if rheumatism }\end{array}\end{array}$ & Regiment fixed effects \\
\hline In 1900 & $\begin{array}{l}\text { Occupation } \\
\quad=1 \text { if farmer } \\
=1 \text { if professional } \\
=1 \text { if artisan } \\
=1 \text { if laborer } \\
=1 \text { if skilled laborer } \\
=1 \text { if occupation unknown } \\
\text { Age and marital status } \\
\text { Age } \\
=1 \text { if married }\end{array}$ & $\begin{array}{l}\text { City size } \\
\quad=1 \text { if }<8,000 \\
=1 \text { if }>8,000 \text { and }<30,000 \\
=1 \text { if }>30,000\end{array}$ \\
\hline
\end{tabular}

posure, the use of lead-based solder and pipes in plumbing, or the use of lead-based paints.

The second hypothesis is that lead water mains had small but identifiable effects on human health, resulting in blood concentration levels between 10 and $40 \mu \mathrm{g} \mathrm{Pb} / \mathrm{dl}$ and symptoms such as dizziness and reduced hearing acuity. Under this hypothesis, recruits living in cities with lead pipes as of 1900 would have experienced more ailments associated with low levels of lead exposure than recruits living in cities without lead pipes. The coefficients on lead water mains would be positive and statistically significant for dizziness and ear problems, but close to zero and statistically insignificant for more 


\begin{tabular}{|c|c|c|c|c|c|}
\hline \multirow[b]{2}{*}{ Variable } & \multicolumn{5}{|c|}{ Dependent Variable ( $=1$ if recruit reported) } \\
\hline & Dizziness & Ear Problems & Deafness & Kidney Disease & Memory Loss \\
\hline & \multicolumn{5}{|c|}{ Hypothesis 1: Lead water mains had no effect (blood concentration $<10$ ) } \\
\hline \multirow{3}{*}{$\begin{array}{l}\text { Some lead }\left(\beta_{1}\right) \\
\text { All lead }\left(\beta_{2}\right) \\
\text { Relative effect }\end{array}$} & 0 & 0 & 0 & 0 & 0 \\
\hline & 0 & 0 & 0 & 0 & 0 \\
\hline & \multicolumn{5}{|c|}{ Hypothesis 2: Lead water mains had small effect (blood concentration $>10$ and $<40$ ) } \\
\hline Some lead $\left(\beta_{1}\right)$ & + & + & 0 & 0 & 0 \\
\hline All lead $\left(\beta_{2}\right)$ & + & + & 0 & 0 & 0 \\
\hline \multirow[t]{2}{*}{ Relative effect } & $\beta_{1}<\beta_{2}$ & $\beta_{1}<\beta_{2}$ & & & \\
\hline & \multicolumn{5}{|c|}{ Hypothesis 3: Lead water mains had large effect (blood concentration $>40$ ) } \\
\hline Some lead $\left(\beta_{1}\right)$ & + & + & + & + & + \\
\hline All lead $\left(\beta_{2}\right)$ & + & + & + & + & + \\
\hline Relative effect & $\beta_{1}<\beta_{2}$ & $\beta_{1}<\beta_{2}$ & $\beta_{1}<\beta_{2}$ & $\beta_{1}<\beta_{2}$ & $\beta_{1}<\beta_{2}$ \\
\hline
\end{tabular}

serious lead-related ailments such as kidney disease and memory loss. In addition, for dizziness and ear problems, we expect the coefficient on the some-lead dummy to be smaller than the coefficient on the all-lead dummy, because individuals living in cities that used lead mains in conjunction with iron mains would have been exposed to less lead on average than individuals living in cities that used lead mains exclusively. Results consistent with the second hypothesis would suggest that only small amounts of lead dissolved into water as a result of lead service pipes.

The third hypothesis is that lead water mains had large adverse effects on human health, resulting in blood concentration levels greater than $40 \mu \mathrm{g}$ $\mathrm{Pb} / \mathrm{dl}$ and symptoms such as kidney failure and memory loss. Under this hypothesis, recruits living in cities with lead pipes as of 1900 would have experienced more ailments associated with high levels of lead exposure than recruits living in cities without lead pipes. The coefficients on lead water mains would be positive and statistically significant for all of the leadrelated ailments we consider-dizziness, ear problems, deafness, kidney disease, and memory loss. Again, we expect the coefficient on the some-lead dummy to be smaller than the coefficient on the all-lead dummy, because individuals living in cities that used lead mains in conjunction with iron mains would have been exposed to less lead on average than individuals living in cities that used lead mains exclusively. Results consistent with the third hypothesis would suggest that significant amounts of lead dissolved into water as a result of lead service pipes.

Of the three hypotheses, the third strikes us as the least plausible. If the 
use of lead services caused such serious and life-threatening conditions, city residents would have grown increasingly cognizant of the dangers of lead and lead mains and demanded that local and state governments take steps to eradicate lead service pipes. While these patterns are observable in Lowell and Milton, these towns appear to have been outliers and we generally do not observe political outcomes consistent with this. On the contrary, as noted above, all but a handful of the nation's largest cities (those with populations greater than 300,000 ) used, and continued to install, lead services well into the twentieth century, and as late as 1916, engineering journals were claiming that lead was the most attractive metal for service mains.

Table 7.7 reports some of the more important regression results for the variables of interest, $L 1_{i}$ and $L 2_{i}$. (Complete results for all coefficients are available upon request.) There are three notable findings. First, the explanatory power of these models is not high, and all of the pseudo$R$-squareds are less 20 percent. This is consistent with other studies exploring the health of Union Army veterans. Second, overall, the results are most consistent with the second hypothesis: Lead water mains appear to have had a small but identifiable effect on the health of Union Army veterans. Only two mild ailments - dizziness and ear problems - show a robust and significant positive correlation with the use of lead mains. In the case of dizziness (ear problems), recruits living in cities with lead water mains were 50 to 100 percent (15 percent) more likely than recruits living in cities without lead mains to have reported dizziness. More serious symptoms and ailments such as memory loss show no significant correlation with the use of lead services. (Kidney disease shows a correlation in only one model.) Third, whenever we obtain statistically significant results, the estimated coefficient on the all-lead dummy is greater than the estimated coefficient on the some-lead dummy. Because recruits living in cities that used lead mains exclusively would have been exposed to more lead on average than recruits living in cities that used both lead and iron mains, we expect this pattern and view it as weak confirmation that we are estimating reasonable specifications. ${ }^{5}$

It is possible that veterans already in poor health were the most vulnerable to environmental insults, and therefore experienced more severe reactions to lead water mains. To explore this possibility, we restrict our sample to only those recruits who were privates throughout the Civil War on the assumption that they had poorer health than higher-ranking soldiers. Restricting the sample this way does not significantly alter our findings except that lead now appears to have had a much larger impact on the probability that the recruit reports dizziness (see table 7.8, which reports the important

5. Not reported in table 7.7 are our findings for deafness and kidney trouble. We find no statistically significant relationship between lead water mains and deafness, and between lead water mains and kidney tenderness and pain. 


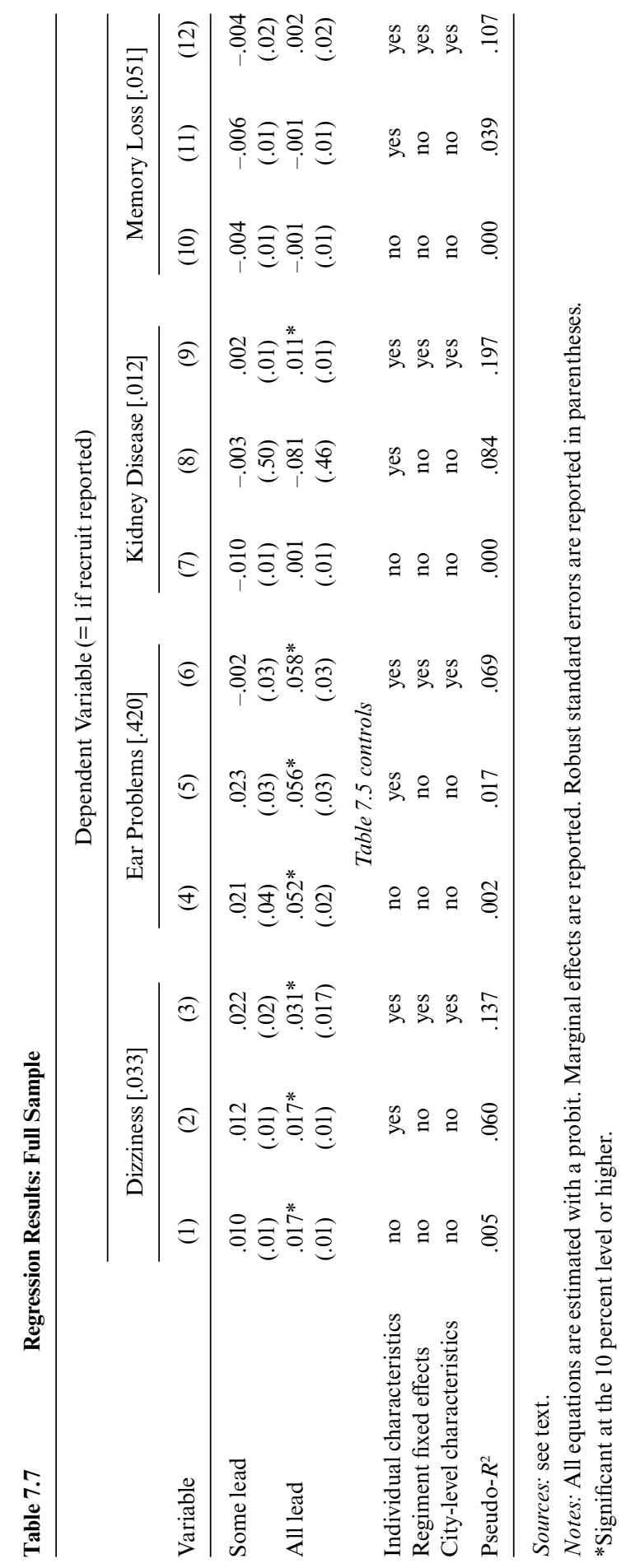




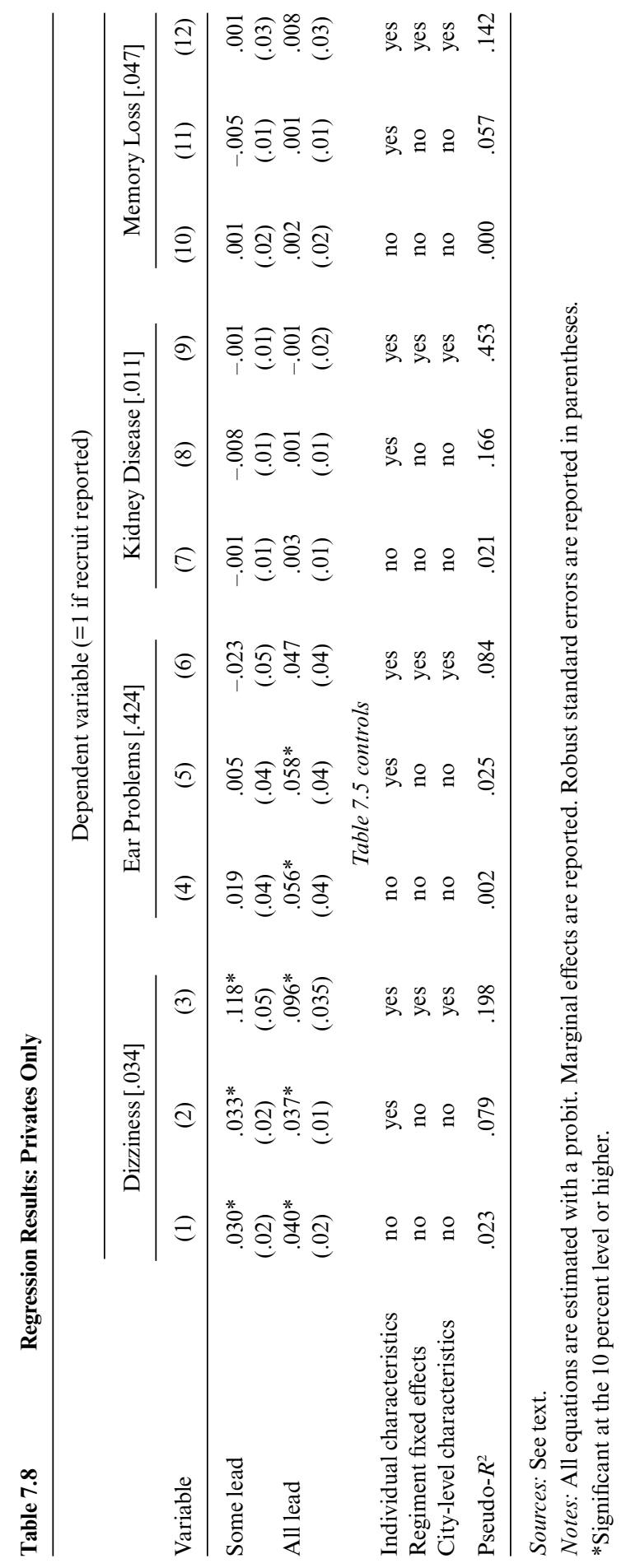


regression results). Complete results are available upon request. Finally, it is important to point out that to the extent that lead water mains affected children more than adults, the results reported in tables 7.7 and 7.8 will understate the adverse effects of lead water mains on the population as a whole.

\subsection{Conclusions}

The central conclusions of this paper are as follows. First, in 1900, lead water mains were pervasive, especially among large cities. In the sixteen largest cities in the United States, all but one used lead mains exclusively or in combination with some other type of main. According to the engineering literature, lead was attractive because it was pliable and easy to work with, and because it did not corrode as quickly as iron and steel. While engineers recognized the dangers of lead poisoning, they believed these benefits often outweighed the costs of using lead services. There were, however, isolated examples (e.g., Lowell and Milton, Massachusetts) where the use of lead services had disastrous consequences. Second, the use of lead service mains does not appear to have had serious effects on the health of Union Army veterans. Veterans living in cities with lead mains reported higher rates of dizziness and ear problems than veterans living in cities without lead, but they did not report higher levels of more serious lead-related ailments such as kidney failure.

In the future, we hope to pursue two related lines of research. First, we hope to quantify the economic costs of lead exposure through drinking water in terms of reduced labor force participation and early death. Second, because lead's effects can be especially serious for the young, it would be desirable to extend this analysis to explore how lead water mains affected the growth and development of children. A promising data set for this area of inquiry is the Intergenerational and Familial Aspects of Aging (ILAS) data compiled by researchers affiliated with the Center for Population Economics at the University of Chicago. Because the ILAS data, among other things, allow one to follow the life course of individuals from birth to death, we will be able to identify the effects of childhood exposure to lead through drinking water on development, morbidity, and premature death.

\section{References}

Aufderheide, A. C., F. D. Neiman, L. E. Wittmers, and G. Rapp. 1981. Lead in bone II: Skeletal-lead content as an indicator of lifetime lead ingestion and the social correlates in an archeological population. American Journal of Physical Anthropology 45:723-35. 
Baker, M. N. 1897. The manual of American water-works. New York: Engineering News.

Centers for Disease Control and Prevention. 1997. Morbidity and mortality weekly report. May.

Charney, E., J. W. Sayre, and M. Coulter. 1980. Increased lead absorption in inner city children: Where does the lead come from? Pediatrics 65:226-31.

Cohen, N., D. Modai, A. Golik, J. Weissgarten, S. Peller, A. Katz, Z. Averbukh, and U. Shaked. 1989. Increased concanavalin A-induced suppressor cell activity in humans with occupational lead exposure. Environmental Research 48:1-6.

Costa, D. L. 2000. Understanding the twentieth-century decline in chronic conditions among older men. Demography 37:53-72.

Deppisch, L. M., J. A. Centeno, D. J. Gemmel, J. David, and N. L. Torres. 1999. Andrew Jackson's exposure to mercury and lead: Poisoned president? Journal of the American Medical Association 282:569-71.

Fischbein, A., P. Tsang, J. J. Luo, J. P. Roboz, J. P. Jiang, and J. G. Bekesi. 1993. The immune system as target for subclinical lead related toxicity. British Journal of Industrial Medicine 50:185-86.

Fogel, R. W. 1986. Nutrition and the decline in mortality since 1700: Some preliminary findings. In Long-term factors in American economic growth, eds. S. Engerman and R. E. Gallman, 439-555. Chicago: University of Chicago Press.

- 2000. Public use tape on the aging of veterans of the Union Army: Military, pension, and medical records, 1860-1940. Version M-5. Chicago: University of Chicago, Graduate School of Business, Center for Population Economics.

Fogel, R. W., and D. L. Costa. 1997. A theory of technophysio evolution, with some implications for forecasting population, health care costs, and pension costs. Demography 34:49-66.

Lanphear, B., and K. J. Rogham. 1997. Pathways of lead exposure in urban children. Environmental Research 74:67-73.

Markowitz, G., and D. Rosner. 2000. "Cater to the children": The role of the lead industry in a public health tragedy, 1900-1955. American Journal of Public Health 90:36-46.

Melosi, Martin V. 2000. The sanitary city: Urban infrastructure from colonial times to the present. Baltimore: Johns Hopkins University Press.

Needleman, H. L., and D. Belinger. 1991. The health effects of low level exposure to lead. Annual Review of Public Health 40:111-40.

Perazella, M. A. 1996. Lead and the kidney: Nephropathy, hypertension, and gout. Connecticut Medicine 60:521-26.

Ravin, J. G., and T. B. Ravin. 1999. What ailed Goya? Journal of Ophthalmology 44:163-70.

Report of the Committee on Service Pipes. 1917. Journal of the New England Water Works Association 31 (3): 323-89.

Sata, F., S. Araki, T. Tanigawa, Y. Morita, S. Sukurai, A. Nakata, and N. Katsuno. 1998. Changes in T cell subpopulations in lead workers. Environmental Research 76:61-64.

Solliway, B. M., A. Schaffer, H. Pratt, and S. Yannai. 1994. A multidisciplinary study of lead-exposed subjects. Environmental Research 67:168-82.

Trepka, M. J., J. Heinrich, C. Krause, C. Schulz, U. Lippold, E. Meyer, and H. E. Wichman. 1997. The internal burden of lead among children in a smelter town: A small area analysis. Environmental Research 72:118-30.

Troesken, W. 1997. The sources of public ownership: Historical evidence from the gas industry. Journal of Law, Economics, and Organization 13:1-27. 
U.S. Department of Commerce and Labor, Bureau of Labor. 1902. Statistics of cities having a population greater than 30,000:1902. Washington, D.C.: GPO.

U.S. Environmental Protection Agency, Office of Water. 2000. Lead in your drinking water. Available at [http://www.epa.gov/safewater/Pubs/lead1.html].

Waldron, H. A., and D. Stöfen. 1974. Sub-clinical lead poisoning. London: Academic Press.

Wisconsin Department of Natural Resources. 1993. Lead in drinking water. Available at [http://www.dnr.state.wi.us/org/water/dwg/lead.html].

Xintaras, C. 1992. Impact of lead-contaminated soil on public health: An analysis paper. Atlanta: U.S. Department of Health and Human Services, Agency for Toxic Substances and Disease Registry. Available at [http:www.atsdr.cdc.gov/exlead. html]. 
